\title{
Influence of herbal extract and storage duration on fruit quality of china lime
}

\begin{abstract}
Thin edible organic coating helped to improve the fruit quality and are consumable without any side effects on health. China lime has good market value both at national and international level. The objective of the work was to study the Influence of herbal extracts and storage duration on fruit quality of china lime. An experiment was conducted at the Post Harvest Laboratory, Department of Horticulture, The University of Agriculture Peshawar during the year 2015-2016. The research was carried out by using Completely Randomized Design (CRD) with two factors repeated three times. The fruits of china lime were treated with various herbal extracts like ginger, garlic, lemon grass and chilli and stored for 40 days at temperature $20 \pm 10 \mathrm{C}$ with relative humidity $45-50 \%$. The treated fruits of china lime were analyzed for various physicchemical attributes at $0,10,20,30$, and 40 days intervals. The post-harvest application of herbal extracts and storage durations significantly influenced most of qualitative. A significant variation was recorded for various quality attributes when treated the china lime fruit with herbal extracts. However, less percent weight loss $(20.79 \%)$, fruit juice $\mathrm{pH}(2.75)$, TSS (5.880Brix), and maximum fruit firmness $(1.51 \mathrm{kgcm}-2)$, percent titratable acidity $(6.01 \%)$, ascorbic acid contents $(16.86 \mathrm{mg} 100 \mathrm{ml}-1)$, was recorded in fruits treated with garlic extracts. While, concerning storage duration, all the variables studied showed a significant difference after studying there physicalchemcial characteristics. It is concluded from the significant findings of present research that the china lime fruits should be treated with garlic extract and stored for 30 days to retain most of the quality attributes. It was concluded that post harvest treatments of herbal extract were more effective to maintain the quality attributes of china lime fruits in order to retain the maximum physical-chemical characteristics of china lime fruits. The fruit could be treated with garlic extract in order to store for 30 days at room temperature $20 \pm 10 \mathrm{C}$ with relative humidity of $45-50 \%$ to maintain the quality attributes.
\end{abstract}

Keywords: citrus, citrus aurantifolia, edible coating, organic agriculture, shelf life
Volume 3 Issue 3 - 2019

\author{
Maryam Samad,' Muhammad Sajid,' Ibrar \\ Hussain, ${ }^{2}$ Nadia Samad,' Nazia Jan' \\ 'Department of Horticulture, The University of Agriculture, \\ Pakistan \\ ${ }^{2}$ Agronomist, Ph.D, Centro de Ciências Agrárias, Universidade \\ Estadual de Londrina, Brazil
}

Correspondence: Ibrar Hussain, Agronomist, Centro de Ciências Agrárias, Universidade Estadual de Londrina, PO. Box 10.01 I, ZIP 86.057-970, Londrina-PR, Brazil,

Email ibrar_horti@yahoo.com,hussain0334@uel.br

Received: May 29, 2019 | Published: June 07, 2019

\section{Introduction}

Citrus is non climacteric fruit and had greater shelf life as compared to climacteric fruits. In citrus fruits during maturity and ripening stage the composition of ethylene and respiration are not varied as like in climacteric fruits. Citrus fruits might have some post harvest physiological problems if not handled and stored appropriately. Weight loss and some physiological disorders are the major problems of citrus which not only cause quantitative losses but it also result qualitative problems such as softening, shriveling and wilting. Among these water loss is considered as the most important physiological disorder. ${ }^{1}$

Among citrus crops, China lime 'Citrus aurantifolia' is the third crucial species after orange and mandarin ${ }^{2}$ family belongs to Rutaceae and citrus genus with sub family Aurantioideae. Citrus includes those fruits which contain enough quantity of citric acid and hence, classified as acid fruits. The citrus is medium evergreen tree having different size and shapes of fruits containing fragrance, juice and flavour. The skin of fruit is rough and bright, it prevents fruit from external injuries.

Shelf life of food means the useful storage life and for any food, it is an essential property. In food chain shelf life has a great importance to everybody from producer up to consumer. ${ }^{4}$ Characteristic changes develop in food at the end of shelf life in aroma, taste, appearance or texture which are considered undesirable or unacceptable. ${ }^{5}$ Basically these changes might be due to the chemical reactions such as, oxidation microbial and biochemical changes during storage. These reactions resulted from reactions catalyzed by endogenous enzymes and eventually lead to enzymatic browning, proteolysis and lipolysis. ${ }^{6}$

Various diseases and pest caused damages to citrus fruit during growth, harvesting, packing, transportation, marketing and storage (Ajibola et al., 2009). In food spoilage and deterioration, fungi are the main cause worldwide, which ranked second position to insect. ${ }^{7}$ To reduce these losses from infestation of potential or actual insects and fungal diseases, various chemical and physical preservation practices were performed to avoid food spoilage and deterioration. One of the phytosanitary practices for citrus fruits is cold storage especially when delivering fruits from detrimental insect pest harboring areas. ${ }^{8}$ But on the other hand cold sterilization may cause chilling injury especially in china lime. ${ }^{9}$

China lime is the second most sensitive citrus crop to chilling injury. ${ }^{10}$ Citrus fruits are susceptible to chilling injury since; originated from subtropical climate. ${ }^{11}$ On the Flavedo surface chilling injury cause pitting and exhibit a lesion with dark color and sunken nature ${ }^{11}$ which adversely affect the post-harvest quality of china lime, hence, the marketable value ultimately reduced. ${ }^{12}$ While the chemical treatments may cause hazardous effect on citrus consumer for long term. In consumer the awareness regarding the impact of chemical 
preservative is recently increased and people changed their mind to use natural preservative or additives in food product instead of chemicals. ${ }^{13}$

It is admirable to know that the use of medicinal herb (plants have phytochmicals) has begun to increase and become more popular in present situation. Nowadays, some of the food ingredients such as ginger, garlic and lemon grass are using for their medicinal values like antioxidant and antimicrobial properties. ${ }^{14}$ Garlic and ginger extracts has the capability to inhibit the growth of various bacteria and fungi. ${ }^{15}$ The phytochemical compound of garlic are allicin, dially disulphate and thiosulphuric acid which inhibit the growth of microbes. ${ }^{16}$ Gingerol, zingiberol, paradole, bisabolene and zingiberine are phenolic compunds produce by ginger. ${ }^{17}$ These compounds are responsible for both the anti-fungal and antibacterial activity of garlic and ginger. ${ }^{6}$ Therefore, the current study aiming to control the postharvest losses of china lime fruits with natural additive and avoid the use of injurious chemicals. The research has objective, to determine the appropriate herbal extract in order to maintain better fruit quality of china lime during storage and optimum storage duration for china lime fruits with herbal preservatives.

\section{Materials and methods}

Evaluation of herbal extracts and storage duration on fruit quality of china lime was carried out at Post Harvest Laboratory, De Citrus aurantifolia partment of Horticulture, The University of Agriculture Peshawar during the year 2015-2016 at room temperature of $\left(20 \pm 1^{\circ} \mathrm{C}\right)$ with relative humidity of $45-50 \%$. The experiment was carried out by using Completely Randomized Design (CRD) with two factors. For analyzing various qualitative attributes, three randomly selected fruits of each treatment were tested in post harvest laboratory.

The extraction process was carried out in the Laboratory of Weed Science Department, The University of Agriculture Peshawar. Leaves of lemon grass, garlic cloves, ginger corms and chili fruits were used to obtain extract. The leaves, cloves, corms and fruits were washed with running water in order to get rid of dirt and then dehydrated overnight in the laboratory electric oven at $70^{\circ} \mathrm{C}$. After drying each was then crushed individually by using grinder in order to make powdered. This was further preserved in glass bottles for future use. ${ }^{18}$

From already prepared herbal powder $50 \mathrm{~g}$ of each was dissolved in $450 \mathrm{ml}$ distilled water in order to make 10 percent solution $(\mathrm{w} / \mathrm{v}){ }^{19}$ The solution was kept for 24 hours in a beaker. ${ }^{20}$ After 24 hours the fruits were dipped in the required solution and let them for 10 minutes. The treated fruits were then air dried and stored according to the experiment. The experiment was consisted of 25 treatments and for each treatment 10 fruits were treated with three replication. Therefore, a total of 750 fruits were used in the experiment.

The experiment was carried out by using Completely Randomized Design (CRD) with two factors. For analyzing various qualitative attributes, three randomly selected fruits of each treatment were tested in post harvest laboratory. The observations were recorded on first day of storage and then subsequently after 10 day's intervals till the end of experiment (up to 40 days of storage). The two factors were Water (control), Garlic, Ginger, Chili, Lemon grass) and evaluated at storage interval of 10,20, 30 and 40 days.

The variables studied were, Percent weight loss, fruit firmness $\left(\mathrm{kgcm}^{-2}\right)$ by using penetrometer (Wagner fruit firmness tester model FT-327) equipped with $8 \mathrm{~mm}$ tip, Juice contents (\%)juice contents were extracted and weighed and data were recorded in grams, $\mathrm{pH}$ using electronic $\mathrm{pH}$ meter (Inolab Level-1), Percent titratable acidity was determined as per the procedure described by Ranganna (1986), Total soluble solid ( $\left.{ }^{\circ} \mathrm{Brix}\right)$ measured with the help of refractometer (Karnco, instruments co.texas), Ascorbic acid content (mg 100 $\mathrm{ml}^{-1}$ ) was calculated as $\mathrm{mg} / 100 \mathrm{ml}$ juice.

\section{Results and discussion}

\section{Percent weight loss}

The percent weight loss of china lime (Table 1) reveal that the application of herbal extract and storage duration significantly influenced. Fruits coated with garlic extract proved to be better in reducing the percent weight loss $(20.79 \%)$ up to minimum level which was statistically similar with the weight loss $(25.75 \%)$ recorded in fruits coated with ginger extract. storage duration data showed that weight loss increased with increase in storage duration from $9.08 \%$ to $46.61 \%$ from 10 days to 40 days respectively. Weight loss in citrus are the major problems of citrus which not only cause quantitative losses but it also result qualitative problems such as softening, shriveling and wilting. ${ }^{1}$ Thin edible coating like herbal of organic origin helped to improve the fruit quality and are eaten without any side effects on health ${ }^{21}$ They worked efficiently against exterior constituents, reducing water losses, gas exchange aroma, flavor and solute passage towards cuticle. ${ }^{22}$ The weight loss was lower in fruits treated with garlic extracts. ${ }^{21}$ Therefore weight loss can be control up to certain level by treating the fruits with herbal extracts like garlic and ginger.

Table I Influence of herbal extract and storage durations on weight loss of china lime fruits

\begin{tabular}{llllll}
\hline \multirow{2}{*}{ Herbal extracts } & \multicolumn{5}{c}{ Storage durations (days) } \\
\cline { 2 - 5 } & $\mathbf{1 0}$ & $\mathbf{2 0}$ & $\mathbf{3 0}$ & $\mathbf{4 0}$ & Mean \\
\hline Control & 14.00 & 29.00 & 40.00 & 52.00 & $33.75 \mathrm{a}$ \\
Ginger & 7.00 & 20.00 & 32.00 & 44.00 & $25.75 \mathrm{bc}$ \\
Garlic & 5.00 & 14.05 & 26.05 & 38.05 & $20.79 \mathrm{c}$ \\
Lemon grass & 9.42 & 25.00 & 37.00 & 49.00 & $30.10 \mathrm{ab}$ \\
Chilli & 10.00 & 26.00 & 38.00 & 50.00 & $31.00 \mathrm{ab}$ \\
Mean & $9.08 \mathrm{~d}$ & $22.8 \mathrm{Ic}$ & $34.6 \mathrm{Ib}$ & $46.61 \mathrm{a}$ & \\
\hline
\end{tabular}

LSD $a .05$ for extract $(E)=7.2020$ and storage durations $(S D)=6.44 I 7$ with mean followed by different letters are significantly different at $5 \%$ level of significance. 


\section{Fruit firmness ( $\mathrm{kgcm}-2)$}

The data pertaining to fruit firmness (Table 2) that there is significant difference for herbal extracts and storage durations on fruit firmness of china lime during storage. The fruits treated with garlic extract, ginger and chili maintain fruit firmness, $1.51 \mathrm{kgcm}^{-2}, 1.48 \mathrm{~kg} \mathrm{~cm}^{-2}$ and $1.46 \mathrm{kgcm}^{-2}$ respectively. The data regarding storage duration showed that firmness was significantly decreased with increase in storage duration. The minimum fruit firmness $\left(1.29 \mathrm{kgcm}^{-2}\right)$ was recorded in fruits stored for 40 days, followed by fruit firmness $\left(1.36 \mathrm{kgcm}^{-2}\right)$ and $\left(1.42 \mathrm{kgcm}^{-2}\right)$ in fruits stored for 20 and 30 days respectively. The fruits during storage loss stability of cell wall due to collapse of pectin as a result the TSS increased and firmness decreased. ${ }^{23}$ The firmness was maximum when fruits like oranges; persimmon treated with garlic extracts. ${ }^{24}$ The aqueous extract of garlic delay the process of ripening, retain firmness for longer time and boost resistance against disorders of storage..$^{25}$

Table 2 Fruit firmness, Juice content, $\mathrm{pH}$, Titratable acidity, influence by herbal extract and storage durations of china lime fruits

\begin{tabular}{|c|c|c|c|c|}
\hline Herbal extracts & Fruit firmness & Juice content & $\mathrm{pH}$ & Titratable acidity \\
\hline Control & $\mathrm{l} .35 \mathrm{~b}$ & $30.1 \mathrm{~b}$ & $2.96 \mathrm{ab}$ & $5.80 \mathrm{c}$ \\
\hline Ginger & $1.49 \mathrm{a}$ & $36.8 \mathrm{a}$ & $2.74 \mathrm{c}$ & $5.96 \mathrm{ab}$ \\
\hline Garlic & $1.5 \mathrm{I} \mathrm{a}$ & $38.3 \mathrm{a}$ & $2.75 \mathrm{c}$ & $6.01 \mathrm{a}$ \\
\hline Lemon Grass & $\mathrm{I} .35 \mathrm{~b}$ & $31.2 \mathrm{~b}$ & $2.93 \mathrm{~b}$ & $5.84 \mathrm{bc}$ \\
\hline Chilli & $1.47 \mathrm{a}$ & $35.4 \mathrm{a}$ & $2.85 \mathrm{a}$ & $5.94 \mathrm{ab}$ \\
\hline $\mathrm{F}$ & $4.66^{*}$ & $10.93 *$ & $21.91 *$ & $3.22 *$ \\
\hline \multicolumn{5}{|c|}{ Storage Duration (Days) } \\
\hline 0 & $1.62 \mathrm{a}$ & $37.86 \mathrm{a}$ & $2.31 \mathrm{~d}$ & $6.30 \mathrm{a}$ \\
\hline 10 & $1.49 \mathrm{~b}$ & $36.24 \mathrm{a}$ & $2.50 \mathrm{~d}$ & $6.03 \mathrm{~b}$ \\
\hline 20 & $\mathrm{I} .43 \mathrm{bc}$ & $35.41 \mathrm{a}$ & $2.90 \mathrm{c}$ & $5.86 \mathrm{c}$ \\
\hline 30 & $1.36 \mathrm{~cd}$ & $32.13 \mathrm{~b}$ & $3.16 \mathrm{~b}$ & $5.68 \mathrm{~d}$ \\
\hline 40 & $1.28 \mathrm{~d}$ & $30.06 \mathrm{~b}$ & $3.35 \mathrm{a}$ & $5.67 \mathrm{~d}$ \\
\hline $\mathrm{F}$ & $11.69 *$ & $8.64 *$ & $195.50 *$ & $31.29 *$ \\
\hline$F(v \times c)$ & $0.77 \mathrm{~ns}$ & I.3Ins & $11.99 \mathrm{~ns}$ & $1.32 \mathrm{~ns}$ \\
\hline $\mathrm{CV}$ & 0.099 & 3.070 & 0.173 & 0.134 \\
\hline
\end{tabular}

Means followed by the same letter are not significantly different at $5 \%$ level of significance by LSD test. ns= non significant and $*=$ Significant at $5 \%$ level of significance.

\section{Percent juice content}

Herbal extract had significant effect on retaining maximum juice content. The maximum juice content $38.3 \%$ and $36.8 \%$ was recorded in fruits coated with garlic and ginger extract respectively, while minimum juice content was noticed in fruits coated with lemon grass extract and control fruits. The data regarding storage duration reveled that with the increase in storage time a significant decrease in juice content was noticed in china lime fruits. Fruit juice content (37.86\%), observed in fresh fruits, which decreased to $(30.66 \%)$ in fruits stored for 40 days.

The citrus fruit quality depends on many factors, percent juice content was also one of the major characters of citrus fruits. The quality of juice was an essential economic feature in citrus industry. The citrus juice is based on sugar content, which is the main economic factor for processing industry, $95 \%$ citrus crops are further processes over to make different drinks. ${ }^{26}$ The fruit juice content decreased with increase in storage duration and similarly the finding of Sonkar et al. ${ }^{27}$ and Yadav et al. ${ }^{28}$ were also in agreement with current research. Garlic extracts has the potential to retain maximum juice content in fruits during storage since, it has essential oil ${ }^{29,30}$ which act like a barrier to moisture loss during storage. ${ }^{31}$

\section{Fruit juice $\mathrm{pH}$}

The mean data of table exhibited that the untreated fruits (control) and fruits treated with lemon grass extracts resulted the maximum fruit juice $\mathrm{pH} 2.96$ and 2.92 respectively. While the lowest fruit juice $\mathrm{pH} 2.74$ and 2.75 was recorded in fruits treated with ginger and garlic extracts. The data concerning the storage duration a significant increase was found in fruit juice $\mathrm{pH}$ with increase in storage duration from $\mathrm{pH} 2.31$ to $3.35 \mathrm{pH}$ in fruits stored 40 days. The china lime fruits with lower $\mathrm{pH}$ are consider excellent as, the lower juice $\mathrm{pH}$ indicate high acidity which is one of the major qualitative attributes of the china lime juice. However, according to the current research, the fruit $\mathrm{pH}$ value of china lime fruit increased with increase in storage duration and among herbal extracts garlic was found best in terms 
of maintaining the juice $\mathrm{pH}$ throughout the 40 days storage duration. The present results are in agreement with the findings of Jadhao et al..$^{32}$ and Yadav et al. ${ }^{33}$ who conducted research on lime and mandarin respectively.

\section{Titratable acidity}

Titratable acidity $(6.01 \%)$ was recorded higher in fruits treated with garlic extracts and lower titratable acidity $(5.80 \%)$ was recorded in the juice of untreated fruits (control). In case of storage durations a significant decrease was recorded in titratable acidity with storage durations. Mean data express that the minimum titratable acidity $(5.67 \%)$ was recorded in the fruits stored for 40 days whereas lower were noted in fresh fruits (control).

In citrus fruits titratable acidity is one of the prime important qualitative features for the reason that sourness is a most vital aspect in china lime acceptability. Acid furnish the quality of tartness to the produce. In china lime juice citric acid is the main acid which develop the flavor. ${ }^{34}$

Generally acidity level decline during ripening because the metabolism of citric acid occur which is the main organic acid of citrus. ${ }^{35}$ Therefore, the titratable acidity level in ripen fruits are usually lower than the acids in half ripen and mature green fruits during storage. The findings of other scientist were reviewed which support the current study. The reduction in titratable acidity during storage of Valencia orange was observed by Dorria et al. ${ }^{36}$ Furthermore, the decline in acidity during storage with increase in maturity could be due to enhancement of sugar substance in fruits which suppose to boost respiratory action during storage in citrus fruits. ${ }^{37}$ This decrease in titratable acidity during storage makes fruits lesser acidic thus it can be more suitable for consumption due to taste. While in contrast the acidity of fruits decreased by treating with garlic extracts which is not in lined with current results. ${ }^{25,38}$

\section{Total soluble solids ( ${ }^{0}$ Brix)}

The total soluble solids content of china lime fruits is significantly affected by post-harvest treatment of herbal extracts and storage duration. Mean data (Table 3) showed that maximum TSS (6.44 Brix) was recorded in untreated fruits (control fruits), while the lower TSS was noted in fruits treated with garlic extract and ginger extracts. With increasing storage duration a significant increase was observed in total soluble solids of china lime fruits. TSS $\left(5.11^{\circ} \mathrm{Brix}\right)$ in untreated fruits stored for 10days was higher $\left(6.55^{\circ} \mathrm{Brix}\right)$ in fruits stored for 40 days.

TSS designates concentration of sugar and amount of soluble components in the flesh, with increase in storage duration the sugar and other components of flesh degraded or distorted. During storage TSS retained by controlling water loss. ${ }^{18}$ The increase in total soluble solids of citrus fruits occurs because the organic acid slowly decline with expansion in the storage duration. ${ }^{37}$ The fact about the increase in total soluble solids was accompanied by raise in sucrose amount and decrease in acid level during storage or may be the reason due to which TSS increase is the glucogenesis, the alteration of organic acid to sugar. ${ }^{39}$ All these statements strongly support our current findings and many other researchers are also in lined with our results such as Rapisarda et al..$^{40}$ and Ye et al. ${ }^{41}$ conducted research works on mandarin storage and found that TSS is increasing with passage of time in mandarin.

\section{Ascorbic acid content (mg. $\left.100 \mathrm{ml}^{-1}\right)$}

The mean data for ascorbic acid (Table 3) showed that maximum (16.86 mg $100 \mathrm{ml}^{-1}$ ) was recorded in the fruits treated with garlic extracts, followed by ginger extract $\left(15.86 \mathrm{mg} 100 \mathrm{ml}^{-1}\right)$. Whereas minimum ascorbic acids $\left(12.32 \mathrm{mg} 100 \mathrm{ml}^{-1}\right)$ were observed in untreated fruits. Regarding storage duration the ascorbic acid contents significantly decreased with increase in storage duration. Ascorbic acids were found maximum $\left(18.7 \mathrm{mg} 100 \mathrm{ml}^{-1}\right)$ in fresh fruits, with lower ascorbic acid $\left(12.12 \mathrm{mg} 100 \mathrm{ml}^{-1}\right)$ in 40 days storage. In early green fruits the ascorbic acid is in high amount with the passage of time in late fruits the amount of vit $\mathrm{C}$ goes to decline (Davey et al, 2000). The decline in vit $\mathrm{C}$ is due to increase in $\mathrm{pH} .{ }^{42}$ The decline in ascorbic acid during storage of citrus fruit was due to oxidation process. ${ }^{42}$ The maximum ascorbic acid was maintained in fruits treated with garlic and ginger extracts. Since, there is essential oil in garlic and ginger. 29,30

Table 3 Total soluble solids, Ascorbic acid and Disease incidence and influence by herbal extract and storage durations of china lime fruits

\begin{tabular}{llll}
\hline Herbal extracts & Titratable acidity & Total soluble solids & Ascorbic acid \\
\hline Control & $5.80 \mathrm{c}$ & $6.44 \mathrm{a}$ & $12.32 \mathrm{~d}$ \\
Ginger & $5.96 \mathrm{ab}$ & $5.9 \mathrm{l} \mathrm{bc}$ & $15.86 \mathrm{~b}$ \\
Garlic & $6.0 \mathrm{I} \mathrm{a}$ & $5.88 \mathrm{c}$ & $16.86 \mathrm{a}$ \\
Lemon Grass & $5.84 \mathrm{bc}$ & $6.17 \mathrm{~b}$ & $14.44 \mathrm{c}$ \\
Chilli & $5.94 \mathrm{ab}$ & $5.99 \mathrm{bc}$ & $15.44 \mathrm{~b}$ \\
$\mathrm{~F}$ & $3.22^{*}$ & $5.80^{*}$ & $23.83^{*}$ \\
Storage Duration (Days) & & & \\
0 & $6.30 \mathrm{a}$ & $5.11 \mathrm{c}$ & $18.7 \mathrm{a}$ \\
I0 & $6.03 \mathrm{~b}$ & $6.15 \mathrm{~b}$ & $16.12 \mathrm{~b}$ \\
20 & $5.86 \mathrm{c}$ & $6.26 \mathrm{ab}$ & $14.5 \mathrm{c}$ \\
30 & $5.68 \mathrm{~d}$ & $6.32 \mathrm{ab}$ & $13.48 \mathrm{c}$ \\
40 & $5.67 \mathrm{~d}$ & $6.55 \mathrm{a}$ & $12.12 \mathrm{~d}$ \\
$\mathrm{~F}$ & $31.29^{*}$ & $33.50^{*}$ & $50.73^{*}$ \\
$\mathrm{~F}(\mathrm{v} \times \mathrm{c})$ & $1.32 \mathrm{~ns}$ & $1.28 \mathrm{~ns}$ & $2.64 \mathrm{~ns}$ \\
$\mathrm{CV}$ & 0.134 & 0.275 & 2.2682 \\
\hline
\end{tabular}

Means followed by the same letter are not significantly different at $5 \%$ level of significance by LSD test. ns= non significant and $*=$ Significant at $5 \%$ level of significance 
It was concluded that post harvest treatments of herbal extract were more effective to maintain the quality attributes of china lime fruits in order to retain the maximum physical-chemical characteristics of china lime fruits. The fruit could be treated with garlic extract in order to store for 30 days at room temperature $20 \pm 1^{\circ} \mathrm{C}$ with relative humidity of $45-50 \%$ to maintain the quality attributes.

\section{Acknowledgments}

None.

\section{Conflicts of interest}

Authors declare that there is no conflict of interest.

\section{References}

1. Grierson W, Miller WM. Storage of citrus fruit. In Fresh citrus fruits, 2nd ed. Wardowski; 2006.

2. Jamil N, Jabeen R, Khan M, et al. Quantitative assessment of juice content, citric acid and sugar content in oranges, sweet lime, lemon and grapes available in fresh fruit market of quetta city. Int J Basic and appl Sci. 2015;15(01):21-24.

3. Vekiari SA, Protopadakis EE, Papadopoulou P, et al. Composition and seasonal variation of the essential oil from leaves and peel of a cretan lemon variety. J Agric Food Chem. 2002;50(1):147-153.

4. Steele R. Understanding and measuring the shelf- life of food. Wood head Publishing Ltd. Cambridge. UK. 2004;243-256

5. Adekalu OA, Agboola DA. Effect of herb treatments on the storability of sweet oranges (Citrus sinensis Osberk) stored in evaporative cooler. Jour of P harvest Tech. 2015;3(02):043-049.

6. Joe MM, Jayachitra J, Vijayapriya M. Antimicrobial activity of some common spices against certain human pathogens. J Med Plant. 2009;3(11):1134-1136.

7. Jarvis JB, Seiler DAL, Ould A, et al. Observation on the enumeration of moulds in Foods and feeding stuff. J Appl Bacteriol. 1983;55:325-336.

8. Houck LG, Jenner JF, Mackey BE. Seasonal variability of the response of desert lemons to rind injury an decay caused by quarantine cold treatments. J Hort Sci. 1990;65(5);611-617.

9. Aung, LH, Jenner JF, Houck LG. Heat Shock induced changes in exocarp soluble sugars of lemons from two climatic regions. Jour of Hort Sci \& Biotech. 2001;76(1):107-111.

10. Chalutz E, Waks J, Schiffmann-Nadel M. A comparison of the responses of different citrus fruit cultivars to storage temperature. Scientia Horticulturae. 1985;25:271-277.

11. Porat R, Pavoincello D, Lurie S, et al. Identification of a grape fruit DNA belonging to a unique class of citrus dehydrins and characterization of its expression patterns under temperature stress conditions. Physiologia Plantarum. 2002;115:598-603.

12. Erkan M, Pekmezci M, Wang YC. Hot water and curing treatments reduce chilling injury and maintain post-harvest quality of 'Valencia' oranges. Int Jour of Food Sci and Tech. 2005;40:91-96.

13. Mohanka R, Priyanka. Plant extract as natural food preservative agains spoilage fungi from processed food. Int J Curr Microbiol App Sci. 2014;3(8);91-98.

14. Chaisawadi S, Thongbute D, Methawiriyaslip W, et al. Preliminary study of antimicrobial activities on medicinal herbs of Thai food ingredients. Acta Hortic. 2003;675:111-114.
15. Akponah E, Okoro IO, Ubogu M, et al. Effects of ethanolic extracts of garlic, ginger and rosemary on the shelf-life of orange juice. Int $J$ Agr Policy and Res. 2013;1(7):197-204.

16. Avato P, Tursil E, Vitali C, et al. Allyl sulphide constituents of garlic volatile oil as antimicrobial agents. Phytomed. 2000;7:239-243.

17. Michael D. Common spices protect bacteria during irradiation. Ame Chem Sci. 2000;2:270-275.

18. Singh H, Al-samari G, Syarhabil M. Exploitation of natural products as an alternative strategy to control postharvest fungal rotting of citrus. Int joun of Sci and Research Publications. 2012;2(3):1-4.

19. Sharma DC, Rani S, Kashyap NP. Oviposition deterrence and ovicidal properties of some plant extracts against potato tuber moth, Phthiorimaea operculella (Zell.). Pesticide Res Jour. 1997;9(2):241-246.

20. Sharma A. Gupta R. Biological activity of some plant extracts against Pieris brassicae (Linn.). Jour of Bio pesticides. 2009;2(1): 26-31.

21. Baldwin EA, Burns JK, Kazokas W, et al. Effect of 2 edible coatings with different permeability characteristics on mango (Mangifera indica L.) ripening during storage. Post harvest Biol Tech. 1999;17:215-220.

22. Wills R, McGlasson B, Graham D, et al. Postharvest: an introduction to the physiology and handling of fruit, vegetables and ornamentals. 2nd edn. Sydney: University of New South Wales Press; 2007.

23. Safizadeh MA. Vacuum infiltration of polyamines reduces chilling injury and firmness loss of lemon stored at chilling temperature. Int Jour of Agri and Crop Sci. 2013;6(8);445-451.

24. Abd-Allah ASE, Abd El-Moneim AAE, Saleh MMS, et al. Effect of jojoba oil emulsion on prolonging storage periods of Costata Persimmon fruits. Asian J Agr Sci. 2012;4(1):80-88.

25. Kamel HM. Impact of garlic oil, seaweed extract and imazalil on keeping quality of valencia orange fruits during cold storage. Journal of horticultural science \& ornamental plants. 2014;6 (3):116-125.

26. Mouei, RA, Choumane W. Physiochemical juice characteristics of various citrus species in syria. Int Jour of Plant \& Soil Sci. 2014;3(9):1083-1095.

27. Sonkar RK, Sarnaik DA, Dikshit SN, et al. Individual stretch cling film wrapped kinnow mandarin under ambient storage. Indian $J$ of Hort. 2009;66:22-27.

28. Yadav M, Kumar N, Singh DB, et al. Effect of postharvest treatments on shelf life and quality of kinnow mandarin. Indian J of Hort. 2010;67:243248.

29. Nakatani N. Phenolic antioxidants from herbs and spices Jour of Biofactors. 2000;13:141-146.

30. Ilondu, EM, Ejechi BO, Souzey JA. Microbial stability of jam prepared from Velvet tamarind and preserved by combined process. Nigerian Jor of Micro. 2001;5:93-96.

31. Nath A, Barman K, Chandra S, et al. Effect of plant extracts on quality of khasi mandarin (citrus reticulata blanco) fruits during ambient storage. Food Bioprocess Tech. 2012;6:470-474.

32. Jadhao SD, Borkar PA, Borkar SL, et al. Effect of different treatments and packaging materials on biochemical changes during storage of kagzi lime. Asian Jour of Bio Sci. 2008;3(2):247-250.

33. Yadav MK, Singh GK, Parmveer NL, et al. Response of GA3, Ca (NO3)2, bavisteen and neem extract on the storage life of Nagpur mandarin (Citrus reticulata Blanco). Indian J. of Arid Hort. 2006;1(1):80-82.

34. Sharma A, Ghuman BS. Evaluation of on-farm waxing and grading prototype for fresh kinnow fruits. Indian J of Hort. 2009;66: 288-290. 
35. Monselise SP. Citrus. In: Monselise SP, editor. Handbook of fruit set and development, CRC Press, Boca Raton; 1986;87-108.

36. Dorria, MA, Safinaz ME, El-Mallah MH. Jojoba oil as a novel coating for exported Valencia orange fruit. Part 1: The use of Trans (Isomerized) Jojoba oil. American-Eurasian. J Agric and Enviro Sci. 2007;2(2):173181.

37. Ladaniya MS. Physico-chemical, respiratory and fungicide residue changes in wax coated mandarin fruit stored at chilling temperature with intermittent warming. Jour of Food Sci Tech. 2011;48(2):150-158.

38. Elham ZA, Sawsan, YE. Effect of oil coating and different wrapping materials on prolonging storage periods of florida prince peach fruits. Jour of App Sci Res. 2013;9(4):2927-2937.
39. Echeverria E, Ismail M. Sugars unrelated to Brix changes in stored citrus fruits. Hort Science. 1990;25:710-716.

40. Rapisarda P, Bellomo S, Fabroni S, et al. Juice quality of two new mandarin-like hybrids (Citrus clementina Hort. ex Tan x Citrus sinensis L. Osbeck) containing anthocyanins. Jour of Agr and Food Chemi. 2008;56:2074-2078.

41. Ye MZ, Chen QX, Xu JZ, et al. Some physiological changes and storability of citrus fruits during storage. Plant Phys Communications. 2000;36:125127.

42. Emese J, Nagymate PF. The stability of vitamin $\mathrm{C}$ in different beverages. British Food Jour. 2008;110;(3):296-309. 